\title{
Prototype Burner Control of Gas Fuel Oven Machine using Fuzzy Logic Control and Wireless Data Monitoring
}

\section{Prototipe Burner Control Mesin Oven Berbahan Bakar Gas menggunakan Fuzzy Logic Control dan Monitoring Data secara Wireless}

\author{
Imam Wahyu Putra Perkasa'), Fachrudin Hunaini ${ }^{2)}$, Sabar Setiawidayat ${ }^{3)}$ \\ ${ }^{1,2,3)}$ Departement Electrical Engineering, Widyagama University Malang, Indonesia \\ 1)imamwahyu0412@gmail.com \\ 2) fachrudin_h@widyagama.ac.id \\ 3) masdapro@yahoo.com
}

\begin{abstract}
In the food processing industry that requires a roasting process using an oven machine, the temperature stability produced by the oven machine greatly affects the output produced. Oven machines that are often used are electric and gas oven machines, the burner control system maximizes the use of gas to fuel the oven engine. This system utilizes input from the DS18B20 temperature sensor which is used to read the temperature in the oven engine. The temperature control of the gas-fired burner control system is carried out by a microcontroller using a fuzzy logic method to control the gas valve in the form of a servo motor to open and close the gas valve automatically. For monitoring and controlling the work of the burner control using Internet of things (IoT) technology by utilizing the NodeMCU ESP8266 microcontroller as a processor and sending data wirelessly to an android smartphone via the BLYNK application which can make it easier for users to get information about actual temperature, setting temperature and timer. By using the fuzzy Sugeno, this system can regulate the gas servo valve with an accuracy rate of $99.93 \%$.
\end{abstract}

Keywords: Gas oven; Burner control; Fuzzy logic; Internet of things.

Abstrak.- Pada industri pengolahan makanan yang memerlukan proses pemanggangan menggunakan mesin oven, kestabilan suhu yang dihasilkan mesin oven sangat berpengaruh pada output yang dihasilkan. mesin oven yang sering digunakan yaitu mesin oven listrik dan gas, sistem burner control memaksimalkan penggunaan gas untuk bahan bakar mesin oven, Sistem ini memanfaatkan input dari sensor suhu DS18B20 yang digunakan membaca temperatur dalam mesin oven. Pengendalian suhu sistem burner control berbahan bakar gas dikerjakan mikrokontroller dengan menggunakan metode logika fuzzy untuk mengendalikan valve gas yang berupa motor servo untuk buka tutup valve gas secara otomatis. Untuk monitoring dan controlling kerja dari burner control ini menggunakan teknologi Internet of things (IoT) dengan memanfaatkan mikrokontroller NodeMCU ESP8266 sebagai pemroses dan mengirimkan data secara nirkabel ke smartphone android lewat aplikasi BLYNK yang dapat memudahkan user untuk mendapatkan informasi tentang suhu aktual, mengatur setpoint suhu dan timer. Dengan menggunakan fuzzy sugeno sistem ini bisa mengatur servo valve gas dengan tingkat akurasi mencapai 99,96\%.

Kata Kunci : Oven gas; Burner control; Logika Fuzzy; Internet of things. 


\section{PENDAHULUAN}

Pada industri pengolahan makanan khususnya yang bahan baku produksinya memerlukan proses baking (pemanggangan) menggunakan mesin oven, dalam proses baking dalam oven ini menjadi hal sangat penting untuk menentukan hasil produksi tersebut ,dimana kestabilan suhu yang dihasilkan mesin oven sangat berpengaruh pada output yang dihasilkan, ada beberapa jenis mesin oven yang sering digunakan yaitu mesin oven listrik dan gas, pada penggunaanya oven listrik lebih mudah dalam pengendalian suhunya dibandingkan oven gas. oven listrik dalam pengendalian temperatur umumnya menggunakan sensor thermocouple dan thermostat sebagai pengatur pensaklaran elemen pemanas. Sedangkan pengendalian waktu pada oven umumnya menggunakan timer [1]. kali ini akan memaksimalkan penggunaan gas untuk bahan bakar mesin oven, bahan bakar gas terutama LPG memiliki nilai kalor yang cukup tinggi sekitar $47081 \mathrm{~kJ} / \mathrm{kg}$ yang dapat memberi keunggulan dalam proses [2], kendala yang ada pada mesin oven gas adalah kurang maksimal nya pengendalian suhu yang terjadi dan tentunya sangat berpengaruh besar pada hasil produksi dan juga penggunaan gas yang kurang efisien.

Pada penelitian tentang kendali suhu mesin oven yang lebih dahulu masih banyak yang menggunakan metode PID, dimana pengontrol PID akan menghasilkan aksi kontrol dengan membandingkan kesalahan atau error yang merupakan selisih dari process variable dan set point sebagai masukan, berbeda dengan fuzzy logic control yang memiliki cara yang lebih sederhana dalam memberikan keputusan seperti halnya manusia berpikir, dengan menafsirkan data dan mencari solusi yang lebih tepat [3]. Metode kontrol logika fuzzy adalah metode yang mempresentasikan suatu nilai linguistik dari suatu variabel ,misalkan variabel suhu yang dinyatakan dengan nilai linguistik panas, sejuk dan dingin. FLC lebih kokoh dibandingkan pengendali PID, karena mencakup daerah operasi yang lebih luas daripada pengendali PID, FLC juga dapat bekerja dengan lingkungan yang banyak gangguan, Selain itu FLC juga lebih mudah dimengerti dan dimodifikasi aturanaturannya. Fuzzy logic controller banyak diaplikasikan pada bidang kendali peralatan rumah tangga seperti kulkas, mesin cuci, penghisap debu, penyejuk udara $(A C)$, dan alat pengatur suhu pemanas pada heater mesin oven [4], Sistem burner control memanfaatkan input dari sensor suhu DS18B20 yang digunakan membaca temperatur ruangan dalam mesin oven. Sensor ini mampu membaca suhu dengan rentang pembacaan dari $-55^{\circ} \mathrm{C}$ hingga $125^{\circ} \mathrm{C}$ dengan ketelitian kurang lebih $0.5^{\circ} \mathrm{C}$ [5]. Pada sistem burner control berbahan bakar gas pengendalian suhu dikerjakan mikrokontroller dengan menggunakan metode logika fuzzy untuk mengendalikan valve gas yang berupa motor servo, kerjanya untuk buka tutup katup valve gas secara otomatis. Kelebihan motor servo dapat bekerja sesuai dengan kapasitas gas yang dibutuhkan mesin oven untuk mencapai kebutuhan setpoint suhu yang diinginkan.

Untuk monitoring proses kerja dari burner control dibuat suatu sistem monitor jarak jauh dengan smartphone dengan bantuan internet untuk kita lebih mudah mengetahui proses kerja burner control dari jarak jauh, Sistem yang dikembangkan meliputi dua bagian yaitu sistem kontrol dan sistem monitor data. Sistem kontrol ini akan mengatur agar suhu yang terjadi akan terus sesuai dengan yang diharapkan, sistem monitor data akan memberikan informasi kepada user tentang keadaan yang sedang berlangsung pada saat itu juga. Pengguna akan lebih mudah dan cepat untuk mendapatkan informasi yang dibutuhkan terkait dengan suhu yang sedang dimonitor saat itu juga. komponen penunjang yang tepat digunakan untuk penelitian ini adalah Node $M C U$, yaitu sebuah mikrokontroller keluarga arduino yang sudah terpasang modul wifi ESP8266 [6]. Penggunaan jaringan internet sebagai jalur komunikasi data memungkinkan sistem ini dapat bekerja dengan cepat. Berdasarkan latar belakang tersebut maka dalam penelitian ini akan dirancang suatu sistem burner control mesin oven berbahan bakar gas menggunakan metode fuzzy logic control untuk mengendalikan dan menjaga kestabilan suhu dalam proses baking, sistem burner control juga dilengkapi dengan monitoring dan controlling jarak jauh yang dapat memudahkan user untuk mendapatkan informasi tentang proses kerja sistem tersebut secara langsung maupun mengontrol sistem tersebut sesuai dengan kebutuhan.

\section{METODE}

\subsection{Mesin Oven}

Mesin oven banyak digunakan pada industri makanan ,terutama industri yang dalam alur produksi nya membutuhkan proses baking ,dimana dalam proses baking tersebut membutuhkan suhu panas dari mesin oven tersebut untuk menghasilkan produk. sementara itu kebanyakan mesin oven otomatis menggunakan energi listrik untuk menggerakan heater sebagai bahan utama pembakaran oven pada penggunaanya Oven listrik lebih mudah dalam pengendalian suhunya dibandingkan oven gas [1]. Namun penggunaan oven listrik dirasa kurang cocok jika digunakan pada industri yang membutuhkan energi panas yang cukup besar untuk proses produksinya, mesin oven gas lebih efektif dalam menyalurkan kalor yang dibutuhkan di proses pembakaran jika dibandingkan dengan heater.

[Figure 1 about here.]

\subsection{Logika Fuzzy}

Metode kontrol logika fuzzy adalah metode yang mempresentasikan suatu nilai linguistik dari suatu variabel, misalkan variabel suhu yang dinyatakan dengan nilai linguistik sejuk, hangat dan panas. Logika 
fuzzy menunjukkan sejauh mana suatu nilai itu benar dan sejauh mana suatu nilai itu salah. Logika fuzzy adalah suatu cara yang tepat untuk memetakan suatu ruang input ke dalam suatu ruang output, mempunyai nilai kontinyu. Fuzzy dinyatakan dalam derajat dari suatu keanggotaan dan derajat dari kebenaran. Oleh sebab itu sesuatu dapat dikatakan sebagian benar dan sebagian salah pada waktu yang sama [7].

\subsection{Arduino Uno}

Arduino merupakan platform yang terdiri dari software dan hardware. Hardware Arduino sama dengan mikrokontroler pada umumnya hanya pada arduino ditambahkan penamaan pin agar mudah diingat. arduino merupakan kit elektronik atau papan rangkaian elektronik yang didalamnya terdapat komponen utama yaitu sebuah chip mikrokontroler dengan jenis $A V R$ dari perusahaan Atmel serta sofware pemrograman yang berlisensi open source [8].

[Figure 2 about here.]

\subsection{Servo Motor Valve}

Motor servo disusun dari sebuah motor DC, gearbox, variabel resistor (VR) atau potensiometer dan rangkaian kontrol. Potensiometer berfungsi untuk menentukan batas maksimum putaran sumbu (axis) motor servo. Sedangkan sudut dari sumbu motor servo diatur berdasarkan lebar pulsa yang ada pada pin kontrol motor servo [9].

\section{[Figure 3 about here.]}

\subsection{Sensor Suhu Ds18b20}

Sensor suhu DS18B20 merupakan komponen elektronika yang dapat menangkap perubahan temperatur. Sensor DS18B20 adalah sensor suhu digital seri terbaru dari Maxim IC. Sensor ini mampu membaca suhu dengan rentang $-55^{\circ} \mathrm{C}$ hingga $125^{\circ} \mathrm{C}$ dengan ketelitian $\left(+/-0.5^{\circ} \mathrm{C}\right)[5]$. sensor DS18B20 ini tidak membutuhkan ADC agar dapat berkomunikasi dengan mikrokontroler dan hanya membutuhkan 1 wire saja untuk mentransfer data suhu yang dibaca (single wiredata bus/l-wire protocol) [10].

[Figure 4 about here.]

\subsection{Rtc Ds3231 (Real Time Clock)}

RTC (Real Time Clock) merupakan jam elektronik berupa chip yag dapat menghitung waktu mulai detik, menit, jam, tanggal, hari, bulan hingga tahun dengan akurat, dan menjaga serta menyimpan data waktu tersebut secara real time. Terdapat berbagai jenis RTC diantaranya DS3231. Pencacah waktu pada RTC lain dapat bergeser (drift) hingga hitungan menit setiap bulannya, terutama pada lingkungan dengan kondisi suhu yang ekstrim [11].

\section{[Figure 5 about here.]}

\subsection{Nodemcu Esp8266}

10.21070/jeeeu.v5i1.1005

NodeMCU adalah sebuah board elektronik yang berbasis chip ESP8266 dengan kemampuan menjalankan fungsi mikrokontroler dan juga koneksi internet (WiFi). Terdapat beberapa pin I/O sehingga dapat dikembangkan menjadi sebuah aplikasi monitoring maupun controlling pada proyek IOT [12].

[Figure 6 about here.]

\subsection{Aplikasi Blynk}

Blynk dirancang untuk Internet of Things dengan tujuan dapat mengontrol hardware dari jarak jauh, dapat menampilkan data sensor, dapat menyimpan data, visual dan melakukan banyak hal canggih lainnya. Ada tiga komponen utama dalam platform yaitu Blynk App, Blynk Server, dan Blynk Library [13].

[Figure 7 about here.]

\section{METODE PENELITIAN}

3.1 Tahap Perencanaan

Berikut adalah desain mekanik dari sistem prototype burner control mesin oven berbahan bakar gas menggunakan metode fuzzy logic control dengan monitoring data secara wireless.

[Figure 8 about here.]

Keterangan gambar :
1. Exhaust Fan
5. Box control
2. Sensor suhu DS18B20 6. servo valve
3. Kompor
7. Selenoid
4. LCD Display
8. Regulator
9.Tabung gas

\subsection{Tahap Pembuatan Sistem}

Tahap ini mulai dilakukan perancangan hardware dan software yang mengacu pada pembuatan konsep dan fitur yang direncakan sebelumnya.

[Figure 9 about here.]

[Figure 10 about here.]

Keterangan dan penjelasan blok diagram gambar 9 adalah sebagai berikut :

\section{Sensor suhu DS18B20}

Sensor suhu DS18B20 sebagai komponen input berfungsi sebagai pembaca nilai suhu aktual mesin oven yang selanjutnya data hasil pembacaannya akan diteruskan dan diproses oleh mikrokontroller.

\section{RTC Module}

RTC Module sebagai komponen input berfungsi untuk menghitung waktu secara real time guna memberikan masukan pada mikrokontroller dalam berapa lama waktu yang dibutuhkan dalam proses 
burner mesin oven yang telah kita tentukan dalam setpoint waktu.

\section{Arduino uno}

Arduino uno merupakan sebuah komponen pemroses data yang diterima dari komponen input dan akan merubah data tersebut menjadi suatu perintah untuk komponen output, dalam hal ini arduino akan dikendalikan menggunakan kendali logika fuzzy untuk menjaga suhu mesin oven agar tetap stabil. Setelah proses inisialisasi maka kita menentukan setpoint suhu dan waktu pemanasan ,setelah api menyala maka selenoid utama gas akan membuka, kemudian sensor suhu akan membaca suhu aktual di dalam mesin oven, jika suhu kurang dari setpoint maka servo valve gas akan membuka penuh, servo valve gas dan kipas exhaust akan bekerja sesuai dengan kapasitas yang dibutuhkan untuk mencapai suhu setpoint dan menjaga kestabilan suhu selama waktu pemanasan belum berakhir, jika waktu pemanasan telah selesai maka selenoid utama gas akan menutup diikuti dengan menutupnya servo valve gas dan matinya kipas exhaust.

Berikut flowchart yang digunakan pada arduino uno :

[Figure 11 about here.]

4. Smartphone (android)

Smartphone sebagai hardware yang sudah dipasang aplikasi blynk dan juga sudah terkoneksi internet berfungsi sebagai tempat user untuk memberikan perintah maupun monitoring sistem burner control secara wireless.

\section{Nodemcu ESP8266}

Fungsi dari nodemcu ESP8266 yang sudah terkoneksi dengan internet ini sebagai tempat komunikasi dengan smartphone dimana Perintah dari aplikasi di android akan diterima subsistem data logger melalui modul NodeMCU ESP8266 dan subsistem data logger akan mengirimkan data yang diminta aplikasi android.

6. Relay

Relay berfungsi sebagai saklar yang digunakan untuk menyalakan pemantik api, selenoid valve dan exhaust fan pada sistem burner control.

\section{Display LCD $16 \times 2$}

LCD 16x2 berfungsi sebagai komponen yang menampilkan data yang diproses oleh arduino selain dari smartphone yang digunakan untuk monitoring jarak jauh ,dalam hal ini yang ditampilkan yaitu suhu aktual ,suhu setpoint dan timer burner control .

\section{Selenoid valve}

Selenoid valve sebagai komponen output berfungsi sebagai valve utama buka tutup gas setelah pemantik api dinyalakan sebelum nantinya kapasitas gas yang keluar akan diatur oleh motor servo.

\section{Motor servo valve}

Motor servo sebagai komponen output berfungsi sebagai valve pengaturan kapasitas gas yang keluar, bekerja sesuai dengan kapasitas heating yang dibutuhkan untuk mencapai suhu yang diinginakan dan menjaga kestabilan suhu selama timer pemanasan yang dibutuhkan.

\section{Kipas exhaust}

Kipas exhaust sebagai komponen output berfungsi untuk menjaga kestabilan suhu selama pemanasan yang dibutuhkan oleh sistem burner control.

\subsection{Penerapan Sistem Kendali Logika Fuzzy}

Dalam sistem burner control digunakan kendali logika fuzzy untuk mengatur suhu pemanasan mesin oven, dengan menggunakan sensor suhu DS18B20 untuk mendeteksi suhu di dalam mesin oven yang memberikan masukan kepada pengendali (Arduino Uno) yang akan diproses untuk menjadi keluaran yaitu motor servo valve Sistem kendali yang digunakan untuk pengaturan motor servo valve adalah logika fuzzy dengan metode sugeno.

[Figure 12 about here.]

[Figure 13 about here.]

\section{HASIL DAN PEMBAHASAN}

\subsection{Pengujian Keseluruhan Sistem}

Pengujian keseluruhan sistem burner control yaitu dengan menggabungkan keseluruhan perangkat keras meliputi mesin oven, kompor, kipas exhaust, pemantik api, selenoid valve dan motor servo valve yang dipasang pada selang LPG, sensor suhu DS18B20 yang terpasang pada bagian dalam mesin oven setelah itu dilanjutkan dengan melakukan perakitan panel kontrol yang didalamnya terdapat arduino uno, relay, power supply 5 volt, trafo stepdown 12 volt untuk power selenoid valve, baterai 3.8 volt untuk power pemantik api, nodemcu ESP8266, pemantik api, terminal blok, LCD 16x2 dan modul RTC.

[Figure 14 about here.]

Setelah semua komponen tergabung maka selanjutnya adalah membuat script untuk arduino sebagai komponen utama dan nodemcu ESP8266 untuk fitur internet of thing atau monitoring data secara wireless. Setelah semua script diupload pada arduino maka berikut adalah tampilan informasi pada LCD.

[Figure 15 about here.]

Gambar 15 menunjukan display pada LCD menunjukan suhu aktual suhu pada mesin oven, setpoint suhu, error suhu atau selisih suhu dari suhu aktual ke setpoint dan yang dimaksud sudut adalah 
posisi kerja pada motor servo valve yang merupakan hasil dari perhitungan fuzzy logic control, setpoint timer yang sudah diatur di aplikasi blynk yang kemudian ditampilkan di LCD dan valve open adalah persentasi valve gas yang terbuka.

\section{[Figure 16 about here.]}

Gambar 16 menunjukan display pada aplikasi blynk dimana kita bisa mengatur setpoint timer dan setpoint suhu serta menerima data suhu aktual dan persentasi valve gas yang terbuka pada mesin oven serta tombol emergency stop untuk mematikan mesin.

\subsection{Data Hasil Pengujian Dan Analisa Sistem Burner Control Mesin Oven}

\section{Pengujian Timer Pada Burner Control}

pengujian timer pada burner control yang didapat saat kita mengatur setpoint timer dari aplikasi blynk, yang kemudian dibandingkan dengan hasil dari perhitungan stopwatch. Dalam pengujian timer terdapat 30x percobaan dengan setpoint yang berbeda.

[Figure 17 about here.]

Gambar 17 menunjukan perhitungan stopwatch dan display setpoint pada LCD.

[Table 1 about here.]

Hasil perhitungan error didapat dari membagi antara selisih perhitungan dari stopwatch dengan setpoint timer yang sudah dijadikan di satuan detik, untuk perhitungan error didapat dari menjumlahkan keseluruhan error kemudian dibagi dari jumlah percobaan, dari hasil pengujian didapat error perhitungan sebesar 0,29\%. Dapat disimpulkan di setiap pengujian masih ada sedikit error, terdapat selisih maksimal 12 detik pada perhitungan timer kerja mesin dan perhitungan stopwatch.

\section{Pengujian Suhu Pada Mesin Oven}

Pengujian kedua adalah menguji suhu pada mesin oven dengan membandingkan hasil pada display LCD dengan thermocouple type $\mathrm{K}$. pengujian ini dilakukan pada 30 kali pengujian pada 30 setpoint suhu yang berbeda.

[Figure 18 about here.]

Gambar 18 menunjukan perbandingan antar pembacaan thermocuple type $\mathrm{K}$ dan pada display LCD.

[Table 2 about here.]

Pada 30 kali percobaan diperoleh error pembacaan sebesar 7\%. Dapat disimpulkan bahwa di setiap pengujian suhu dengan setpoint berbeda masih selisih antara thermocouple type $\mathrm{K}$ yang digunakan sebagai acuan dengan pembacaan sensor suhu DS18B20 yang ditampilkan pada LCD

\subsection{Proses Fuzzy Sugeno}

\section{Proses Fuzzifikasi}

Secara garis besar, metode fuzzy untuk pengendalian sudut motor servo valve ini memiliki 1 input yaitu variabel error suhu yang dideteksi oleh sensor suhu, variabel error suhu didapat dengan menghitung selisih setpoint temperatur dengan suhu aktual temperatur. Sedangkan output menggunakan variabel perbedaan sudut servo valve untuk mengendalikan nyala pengapian oven.

[Figure 19 about here.]

[Figure 20 about here.]

Himpunan fuzzy yang digunakan untuk variabel input adalah error suhu dengan kategori error kecil, error sedang dan error besar. Himpunan fuzzy pada output adalah sudut servo besar,sedang, dan kecil. Persamaan fungsi keanggotaan untuk error suhu seperti dibawah ini :

- Error kecil

$$
\mu_{\text {errorkecil }}(x)=\left\{\begin{array}{lr}
0, & x \leq-43,2 \\
\frac{x-(-43,2)}{-4,8-(-43,2)}, & -43,2 \leq x \leq-4,8 \\
1{ }^{43,2-x}, & -4,8 \leq x \leq 4,8 \\
\hline 43,2-(4,8) & 4,8 \leq x \leq 43,2 \\
0, & x \geq 43,2
\end{array}\right.
$$

- Error sedang

$$
\begin{aligned}
& \mu_{\text {errorsedang }}(x) \\
& =\left\{\begin{array}{cc}
0, & x \leq 16,8 \\
\frac{x-(16,8)}{55,2-(16,8)}, & 16,8 \leq x \leq 55,2 \\
1 & 55,2 \leq x \leq 64,8 \\
\frac{103,2-x}{103,2-(64,8)} & 64,8 \leq x \leq 103,2 \\
0, & x \geq 103,2
\end{array}\right.
\end{aligned}
$$

- Error besar

$$
\begin{aligned}
& \mu_{\text {errorbesar }}(x) \\
& =\left\{\begin{array}{c}
0, \\
\frac{x-(76,8)}{115,2-(76,8)}, \\
1 \\
\frac{163,2-x}{163,2-(124,8)} \\
0,
\end{array}\right.
\end{aligned}
$$

$$
\begin{aligned}
x & \leq 76,8 \\
76,8 & \leq x \leq 115,2 \\
115,2 & \leq x \leq 124,8 \\
124,8 & \leq x \leq 163,2 \\
x & \geq 163,2
\end{aligned}
$$

[Figure 21 about here.]

Parameter untuk output kecil diisi 5, untuk sedang 40 dan untuk besar 70. Parameter ini ditentukan untuk mengatur bukaan sudut servo valve gas yang menentukan hasil pengapian pada mesin oven.

[Figure 22 about here.] 
Rule adalah untuk menentukan kondisi input dalam hal ini adalah error suhu, sehingga akan menghasilkan output.Pengujian dilakukan dengan membandingkan hasil output sudut servo pada tampilan LCD dan matlab dengan perhitungan manual menggunakan metode weighted average.

[Figure 23 about here.]

pada baris pertama menunjukan error suhu atau selisih suhu antara setpoint dan suhu aktual kemudian pada baris kedua menunjukan posisi bukaan sudut servo valve.

[Figure 24 about here.]

Pada gambar 23 menunjukan output sudut sebesar 33,44 dan pada gambar 4.11 output pada rule viewer mennujukan 33,44 Selanjutnya adalah menghitung manual dengan metode weighted average:

$$
\begin{gathered}
W A \\
=\frac{\left(\mu_{\text {errorkecil }} \times \text { besar }\right)+\left(\mu_{\text {errorsedang }} \times \text { Sedang }\right)+\left(\mu_{\text {errorbesar }} \times \text { kecil }\right)}{\mu_{\text {errorkecil }}+\mu_{\text {errorsedang }}+\mu_{\text {errorbesar }}} \\
W A=\frac{(0 \times 70)+(0,559 \times 40)+(0,129 \times 5)}{0,00+0,559+0,129} \\
W A=\frac{22,99}{0,688} \\
W A=33,44
\end{gathered}
$$

[Table 2 about here.]

Hasil perhitungan menggunakan metode weighted average terdapat perbedaan eror $0,04 \%$ dengan output pada LCD dan output yang ditampilkan pada matlab. Dari hasil perbedaan tersebut dapat disimpulkan bahwa tingkat keakuratan model fuzzy sugeno sebesar $99,96 \%$.

\section{PENUTUP}

\subsection{KESIMPULAN}

1. Sistem burner control dapat bekerja sesuai dengan setpoint timer yang ditentukan dengan rata rata error sebesar 0,29\%.

2. Sesuai perancangan sistem burner control mesin oven dapat bekerja untuk mengendalikan suhu sesuai dengan setpoint dengan rata rata error pembacaan suhu sebesar $7 \%$.

3. Sesuai dengan perancangan sistem burner control dapat melakukan monitoring dan controlling dengan menggunakan internet dengan aplikasi blynk dan bisa menampilkan suhu aktual, menampilkan persentasi valve gas yang terbuka serta mengatur setpoint suhu dan timer dari smartphone.

4. Motor servo valve sebagai output dari fuzzy logic control dapat bekerja sebagai pengatur volume gas secara otomatis untuk pengendalian burner sesuai dengan kapasitas yang dibutuhkan dengan tingkat keakuratan menggunakan fuzzy sugeno mencapai $99,96 \%$.

\subsection{SARAN}

1. Dapat dikembangkan dengan menambahkan safety berupa flame detector supaya jika suatu saat pemantik api tidak dapat menghasilkan api maka valve gas akan menutup.

2. Dapat dikembangkan dengan menambahkan flowmeter gas untuk mengetahui kapasitas gas yang sudah terpakai.

3. Untuk pendekatan teknologi internet of things masih bisa dikembangkan lagi agar bisa lebih informatif dan mempermudah user untuk menjalankan sistem.

\section{REFERENSI}

[1]. Setiawan, F. B., Rizqiyanto, M. and Yiwa, J. U. M. (2013) 'Oven Terprogram Berbasis Mikrokontroler', Widya Teknika, 21(2), pp. 1014.

[2]. Djafar, Z. et al. (2018) 'Analisis Prestasi Pengering Kopi Berbasis Bahan Bakar Gas ( LPG )', prosiding seminar ilmiah nasional sains dan teknologi, 4(November), pp. 399-408.

[3]. Maerani, R. and Bakhri, S. (2013) 'Perbandingan Sistem Pengontrolan Pid Konvensional Dengan Pengontrolan Cmac, Fuzzy Logic Dan Ann Pada Water Level', Sigma Epsilon, 17(3), pp. 129-141.

[4]. Wahyono, S. and Arief, M. (2015) 'Seledri Menggunakan Kontrol Fuzzy Logic', Edu Elektrika Journal, 4(2), pp. 21-26.

[6]. Wicaksana, I. S. et al. (2018) 'Perancangan Sistem Monitoring Suhu Gudang', CIASTECH, (1), pp. 503-511.

[7]. Iskandar, J. and Utami, D. K. (2019) 'Penerapan Fuzzy Logic Untuk Meningkatkan Derajat Kebenaran Deteksi Pada Alat Bantu Buta Warna Berbasis Sensor Optik', Komputasi: Jurnal Ilmiah Ilmu Komputer dan Matematika, 16(1), pp. 195202. doi: 10.33751/komputasi.v16i1.1590.

[8]. Risal, M. (2017) 'Sistem Kontrol Sirkulasi Air Dan Pemberian Pakan Pada Akuarium Ikan Hias', Jurnal IT, 8(2), pp. 126-135.

[9]. Insantama, D. A. and Suprianto, B. (2019) 'Rancang Bangun Kendali Level Air Otomatis Pada Tangki Dengan Servo Valve Berbasis Fuzzy Logic Controller Menggunakan Arduino', Jurnal Teknik Elektro, 08(01), pp. 143-151. 
[10]. Nurazizah, E. (2017) 'Rancang Bangun Termometer Digital Berbasis Sensor DS18B20 Untuk Penyandang Tunanetra', e-Proceeding of Engineering, 4(3), pp. 3294-3301.

[11]. K, V. D. and Syaryadhi, M. (2017) 'Monitoring Suhu dan Kelembaban Menggunakan Mikrokontroler ATMega328 pada Proses Dekomposisi Pupuk Kompos', Jurnal Karya Ilmiah Teknik Elektro, 2(3), pp. 91-98.

[12]. Hidayati, N. et al. (2018) 'Prototype Smart Home Dengan Modul NodeMCU ESP8266 Berbasis Internet of Things (IoT)', Teknik Informatika Universitas Islam Majapahit, pp. 1-9.

[13]. Supegina, F. and Setiawan, E. J. (2017) 'Rancang Bangun Iot Temperature Controller Untuk Enclosure Bts Berbasis Microcontroller Wemos Dan Android', Jurnal Teknologi Elektro, Universitas Mercu Buana, 8(2), pp. 145-150.

Conflict of Interest Statement: The author declares that the research was conducted in the absence of any commercial or financial relationships that could be construed as a potential conflict of interest.

Copyright (C) 2021 Author [s]. This is an open access article distributed un- der the terms of the Creative Commons Attribution License (CC BY). The use, distribution or reproduction in other forums is permitted, provided the original author(s) and the copyright owner(s) are credited and that the original publication in this journal is cited, in accordance with accepted academic practice. No use, distribution or reproduction is permitted which does not comply with these terms. 
$\pi \sqrt{A} \sqrt{A} \square \int \begin{aligned} & \text { Journal of Electrical and Electronic Engineering-UMSIDA } \\ & \text { ISSN 2460-9250 (print), ISSN 2540-8658 (online) }\end{aligned}$

Vol. 5, No. 1, April 2021

10.21070/jeeeu.v5i1.1005

DAFTAR TABEL

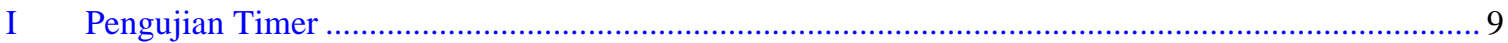

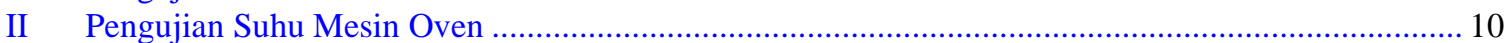

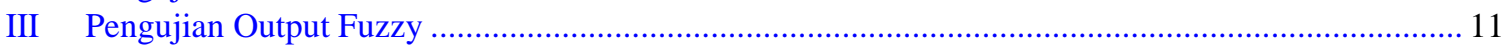


Table I. Pengujian Timer

\begin{tabular}{|c|c|c|c|}
\hline no & Setpoint timer & Hasil perhitungan stopwath & Error \\
\hline 1 & (2 menit) 120 detik & 121 detik & $0,8 \%$ \\
\hline 2 & (5 menit) 300 detik & 303 detik & $1 \%$ \\
\hline 3 & (8 menit) 480 detik & 482 detik & $0,42 \%$ \\
\hline 4 & (10 menit) 600 detik & 605 detik & $0,8 \%$ \\
\hline 5 & (13 menit) 780 detik & 785 detik & $0,64 \%$ \\
\hline 6 & (15 menit) 900 detik: & 888 detik & $1,33 \%$ \\
\hline 7 & (20 menit) 1200 datik & 1205 detik & $0,42 \%$ \\
\hline 8 & (25 menit) 1500 detik & 1505 detik & $0,33 \%$ \\
\hline 9 & (30 menit) 1800 detik & 1790 detik: & $0,55 \%$ \\
\hline 10 & (35 menit) 2100 daik: & 2107 detik: & $0,33 \%$ \\
\hline 11 & (40 menit) 2400 daik & 2403 detik: & $0,12 \%$ \\
\hline 12 & (45 menit) 2700 detik & 2705 detik & $0,18 \%$ \\
\hline 13 & (48 menit) 2880 derik & 2882 detik & $0,07 \%$ \\
\hline 14 & (50 menit) 3000 desik & 3008 detik & $0,26 \%$ \\
\hline 15 & (53 menit) 3180 deik & 3182 detik & $0,06 \%$ \\
\hline 16 & (55 menit) 3300 daik & 3305 detik & $0,15 \%$ \\
\hline 17 & (58 menit) 3480 detik & 3487 detik & $0,20 \%$ \\
\hline 18 & (60 menit) 3600 darik & 3603 detik & $0,08 \%$ \\
\hline 19 & (63 menit) 3780 datik & 3784 detik & $0,1 \%$ \\
\hline 20 & (65 menit) 3900 detik & 3905 detik & $0,13 \%$ \\
\hline 21 & (68 menit) 4080 datik & 4083 detik & $0,07 \%$ \\
\hline 22 & (70 menit) 4200 detik & 4202 detik & $0,05 \%$ \\
\hline 23 & (73 menit) 4380 daik & 4382 detik & $0,05 \%$ \\
\hline 24 & (75 menit) 4500 desik & 4504 detik: & $0,09 \%$ \\
\hline 25 & (78 menit) 4680 datik & 4683 detik & $0,06 \%$ \\
\hline 26 & (80 menit) 4800 detik & 4802 detik & $0,04 \%$ \\
\hline 27 & (83 menit) 4980 denik & 4983 detik & $0,06 \%$ \\
\hline 28 & (85 menit) 5100 datik & 5103 detik & $0,06 \%$ \\
\hline 29 & (88 menit) 5280 daik & 5282 detik & $0,04 \%$ \\
\hline 30 & (90 menit) 5400 datik & 5403 detik & $0,06 \%$ \\
\hline \multicolumn{3}{|c|}{ [Rata rata error } & $0,29 \%$ \\
\hline
\end{tabular}


Table II. Pengujian Suhu Mesin Oven

\begin{tabular}{|c|c|c|c|c|}
\hline no & $\begin{array}{l}\text { Setpoint } \\
\text { suhu }\end{array}$ & $\begin{array}{l}\text { Suhu altual pada } \\
\text { LCD }\left({ }^{\circ} \mathrm{C}\right)\end{array}$ & $\begin{array}{l}\text { Pembacaan pada thermocouple } \\
\text { type } \mathrm{K}\left({ }^{\circ} \mathrm{C}\right)\end{array}$ & Error \\
\hline 1 & 50 & 58 & 64 & $9 \%$ \\
\hline 2 & 53 & 60 & 66 & $9 \%$ \\
\hline 3 & 57 & 65 & 70 & $7 \%$ \\
\hline 4 & 60 & 65 & 70 & $7 \%$ \\
\hline 5 & 63 & $6 ?$ & 71 & $6 \%$ \\
\hline 6 & 65 & 67 & 74 & $9 \%$ \\
\hline 7 & 67 & 70 & 76 & $8 \%$ \\
\hline 8 & 70 & 72 & 78 & $8 \%$ \\
\hline 9 & 73 & 75 & 80 & $6 \%$ \\
\hline 10 & 75 & 76 & 83 & $8 \%$ \\
\hline 11 & 77 & 79 & 85 & $7 \%$ \\
\hline 12 & 80 & 81 & 87 & $7 \%$ \\
\hline 13 & 83 & 84 & 90 & $7 \%$ \\
\hline 14 & 85 & 87 & 93 & $6 \%$ \\
\hline 15 & 87 & 88 & 93 & $5 \%$ \\
\hline 16 & 90 & 91 & 97 & $6 \%$ \\
\hline 17 & 95 & 97 & 105 & $8 \%$ \\
\hline 18 & 98 & 100 & 106 & $6 \%$ \\
\hline 19 & 100 & 101 & 108 & $6 \%$ \\
\hline 20 & 105 & 106 & 111 & $5 \%$ \\
\hline 21 & 108 & 110 & 117 & $6 \%$ \\
\hline 22 & 110 & 111 & 120 & $8 \%$ \\
\hline 23 & 113 & 114 & 120 & $5 \%$ \\
\hline 24 & 115 & 117 & 125 & $6 \%$ \\
\hline 25 & 118 & 119 & 127 & $6 \%$ \\
\hline 26 & 120 & 121 & 129 & $6 \%$ \\
\hline 27 & 125 & 125 & 134 & $7 \%$ \\
\hline 28 & 128 & 129 & 137 & $6 \%$ \\
\hline 29 & 130 & 132 & 140 & $6 \%$ \\
\hline 30 & 135 & 136 & 143 & $5 \%$ \\
\hline \multicolumn{4}{|c|}{ Rata rata error } & $7 \%$ \\
\hline
\end{tabular}


Table III. Perhitungan Output Fuzzy

\begin{tabular}{|c|c|c|c|c|c|c|c|}
\hline No & Setpoint suhu & $\begin{array}{c}\text { Suhu } \\
\text { altual }\end{array}$ & $\begin{array}{l}\text { Error } \\
\text { suhu }\end{array}$ & $\begin{array}{c}\text { Output } \\
\text { sudut pada } \\
\text { LCD }\end{array}$ & $\begin{array}{c}\text { Output } \\
\text { sudut pada } \\
\text { matlab }\end{array}$ & $\begin{array}{c}\text { Perhitungan } \\
\text { weighted } \\
\text { average }\end{array}$ & Error \\
\hline 1 & 125 & 25 & 100 & 9,24 & 9,24 & 9,24 & $0,03 \%$ \\
\hline 2 & 125 & 30 & 95 & 15,9 & 15,9 & 15,87 & $0,18 \%$ \\
\hline 3 & 125 & 35 & 90 & 22,5 & 22,5 & 22,50 & $0,00 \%$ \\
\hline 4 & 125 & 37 & 88 & 25,2 & 25,2 & 25,15 & $0,19 \%$ \\
\hline 5 & 125 & 40 & 85 & 29,1 & 29,1 & 29,13 & $0,10 \%$ \\
\hline 6 & 125 & 43,25 & 81,75 & 33,4 & 33,4 & 33,44 & $0,11 \%$ \\
\hline 7 & 125 & 45 & 80 & 35,8 & 35,8 & 35,76 & $0,12 \%$ \\
\hline 8 & 125 & 48 & 77 & 39,7 & 39,7 & 39,73 & $0,09 \%$ \\
\hline 9 & 125 & 50 & 75 & 40 & 40 & 40,00 & $0,00 \%$ \\
\hline 10 & 125 & 55 & 70 & 40 & 40 & 40,00 & $0,00 \%$ \\
\hline 11 & 125 & 60 & 65 & 40 & 40 & 40,00 & $0,00 \%$ \\
\hline 12 & 125 & 63,5 & 61,5 & 40 & 40 & 40,00 & $0,00 \%$ \\
\hline 13 & 125 & 65 & 60 & 40 & 40 & 40,00 & $0,00 \%$ \\
\hline 14 & 125 & 70 & 55 & 40 & 40 & 40,00 & $0,00 \%$ \\
\hline 15 & 125 & 72,5 & 52,5 & 40 & 40 & 40,00 & $0,00 \%$ \\
\hline 16 & 125 & 75 & 50 & 40 & 40 & 40,00 & $0,00 \%$ \\
\hline 17 & 125 & 77,25 & 47,75 & 40 & 40 & 40,00 & $0,00 \%$ \\
\hline 18 & 125 & 80 & 45 & 40 & 40 & 40,00 & $0,00 \%$ \\
\hline 19 & 125 & 82,5 & 42,5 & 40,8 & 40,8 & 40,80 & $0,01 \%$ \\
\hline 20 & 125 & 85,25 & 39,75 & 43,9 & 43,9 & 43,92 & $0,05 \%$ \\
\hline 21 & 125 & 88 & 37 & 47 & 47 & 47,05 & $0,10 \%$ \\
\hline 22 & 125 & 90,5 & 34,5 & 49,9 & 49,9 & 49,89 & $0,03 \%$ \\
\hline 23 & 125 & 93 & 32 & 52,7 & 52,7 & 52,73 & $0,05 \%$ \\
\hline 24 & 125 & 95,75 & 29,25 & 55,9 & 55,9 & 55,85 & $0,09 \%$ \\
\hline 25 & 125 & 98 & 27 & 58,4 & 58,4 & 58,41 & $0,02 \%$ \\
\hline 26 & 125 & 100 & 25 & 60,7 & 60.7 & 60,68 & $0,03 \%$ \\
\hline 27 & 125 & 105,5 & 19,5 & 66,9 & 66,9 & 66,93 & $0,05 \%$ \\
\hline 28 & 125 & 110 & 15 & 70 & 70 & 70,00 & $0,00 \%$ \\
\hline 29 & 125 & 125 & 0 & 70 & 70 & 70,00 & $0,00 \%$ \\
\hline 30 & 125 & 127,5 & $-2,5$ & 70 & 70 & 70,00 & $0,00 \%$ \\
\hline \multicolumn{7}{|c|}{ Rata rata error } & $0,04 \%$ \\
\hline
\end{tabular}




\section{DAFTAR GAMBAR}

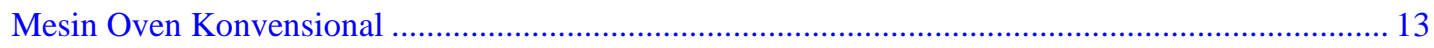

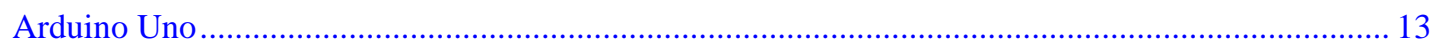

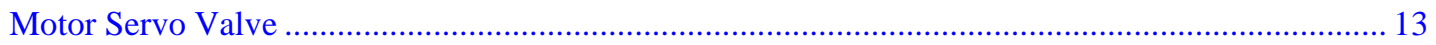

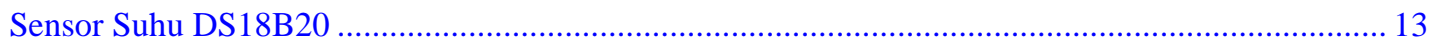

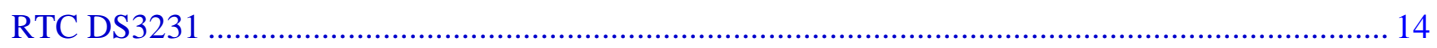

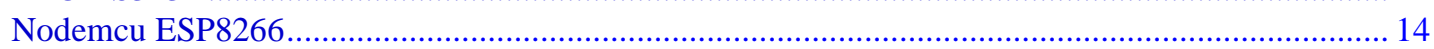

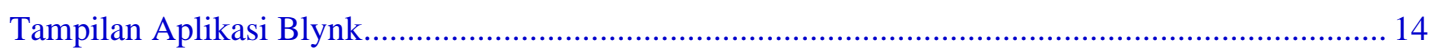

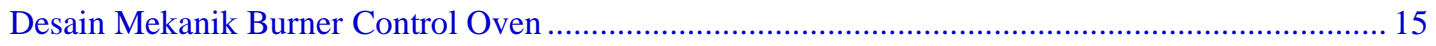

Diagram Blok Keseluruhan Sistem Burner Control Mesin Oven ............................................... 15

10 Skema Rangkaian Elektrik Burner Control Mesin Oven................................................................. 16

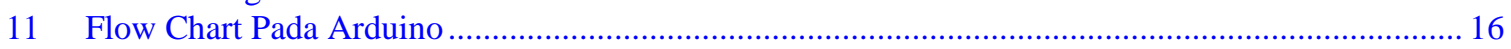

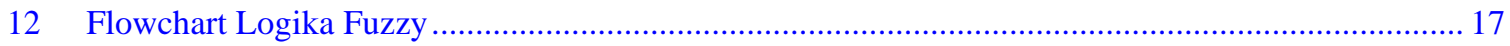

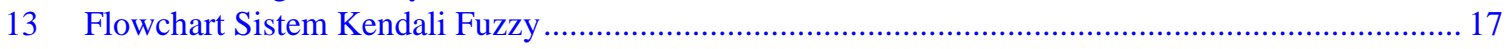

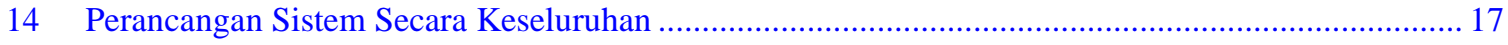

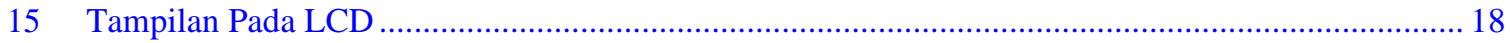

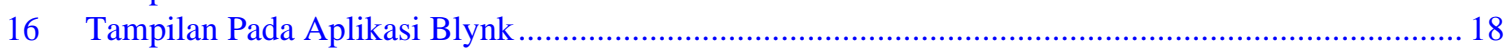

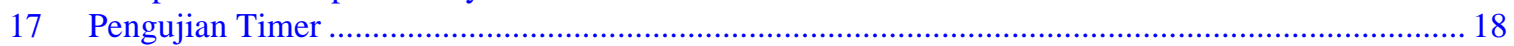

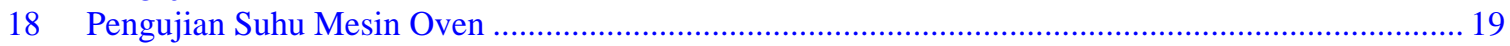

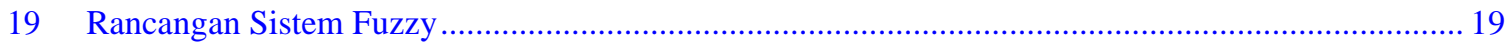

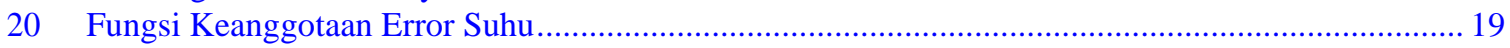

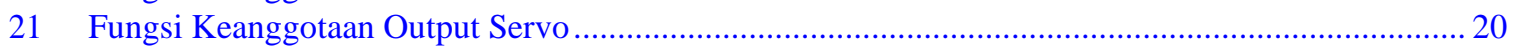

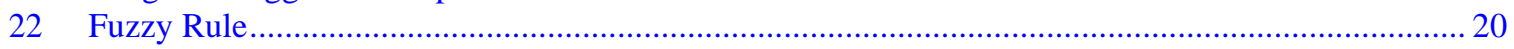

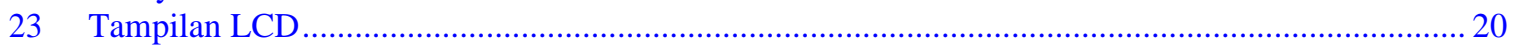

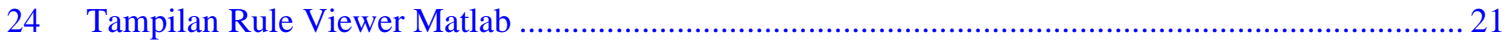


$\pi \sqrt{A} \sqrt{T}]$ Journal of Electrical and Electronic Engineering-UMSIDA

1 4 ISSN 2460-9250 (print), ISSN 2540-8658 (online)

Vol. 5, No. 1, April 2021

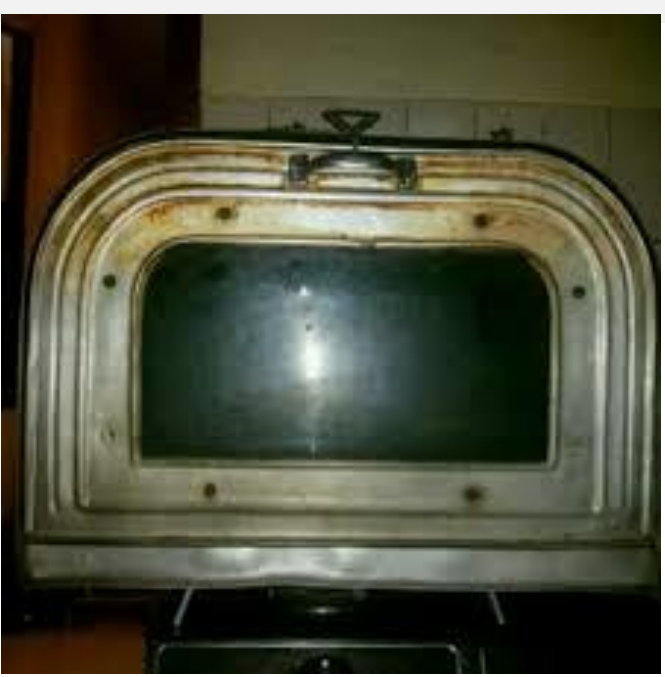

Figure 1. Mesin Oven Konvensional

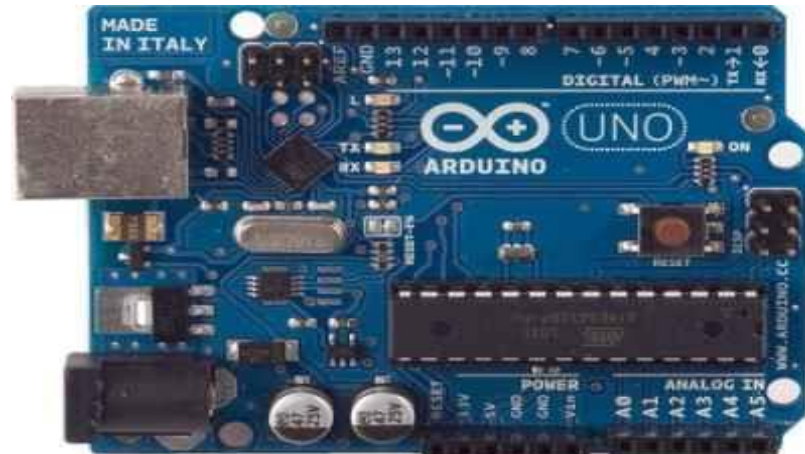

Figure 2. Arduino Uno

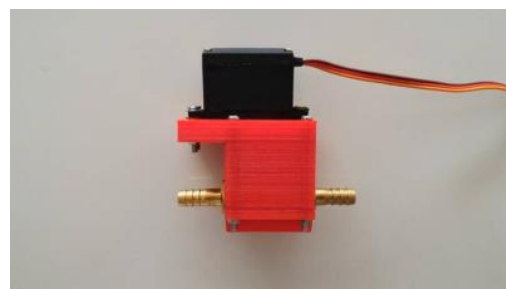

Figure 3. Motor Servo Valve

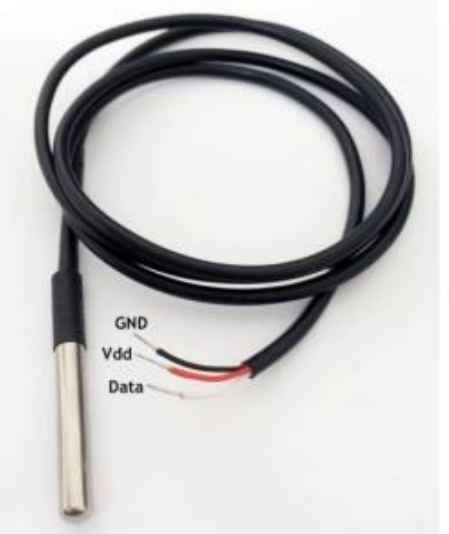

Figure 4. Sensor Suhu DS18B20 
$\sqrt{\mathbb{E}} \sqrt{E} \sqrt{\mathbb{E}}\left[\begin{array}{l}\text { Journal of Electrical and Electronic Engineering-UMSIDA } \\ \text { ISSN 2460-9250 (print), ISSN 2540-8658 (online) }\end{array}\right.$

Vol. 5, No. 1, April 2021

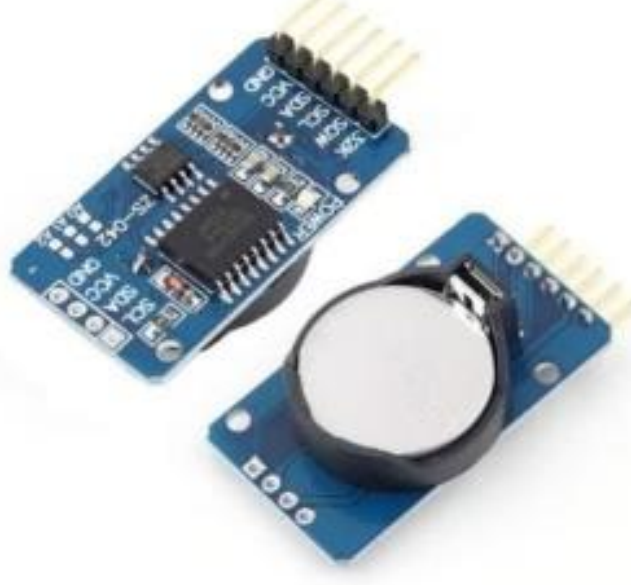

Figure 5. RTC DS3231

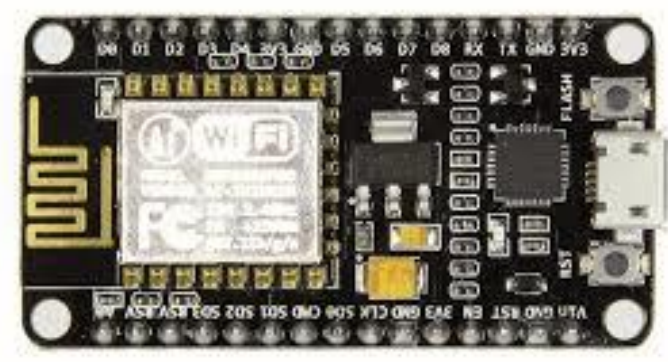

Figure 6. Nodemcu ESP8266
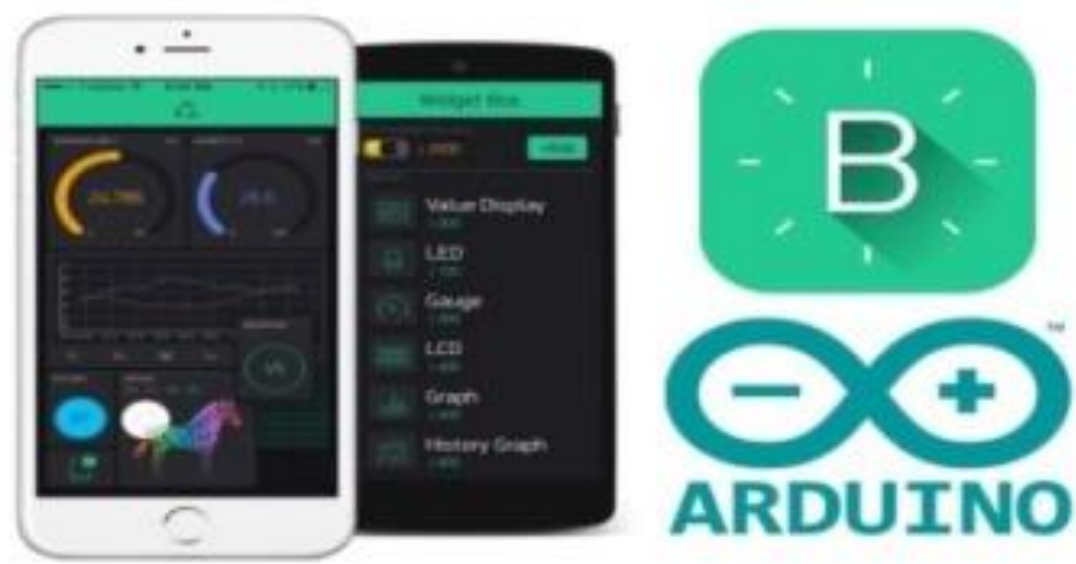

Figure 7. Tampilan Aplikasi Blynk 


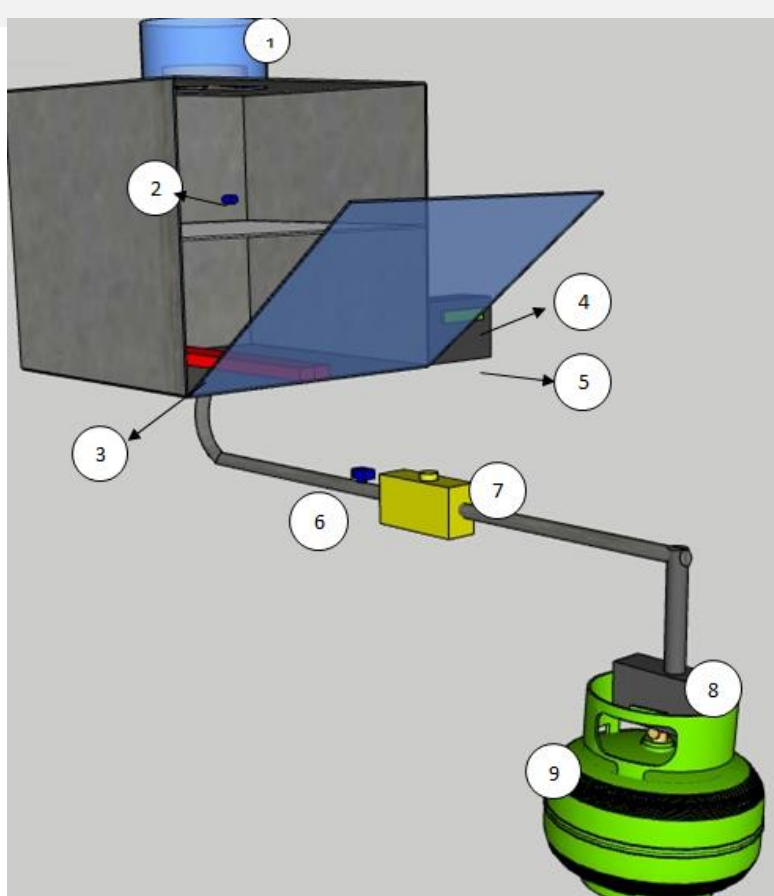

Figure 8. Desain Mekanik Burner Control Oven

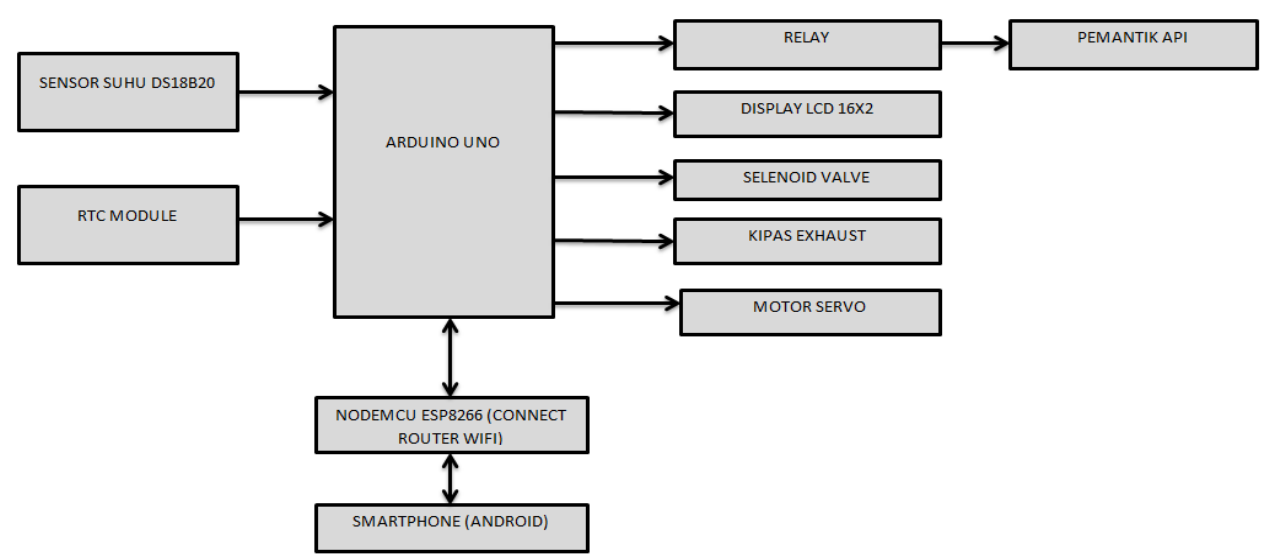

Figure 9. Diagram Blok Keseluruhan Sistem Burner Control Mesin Oven 


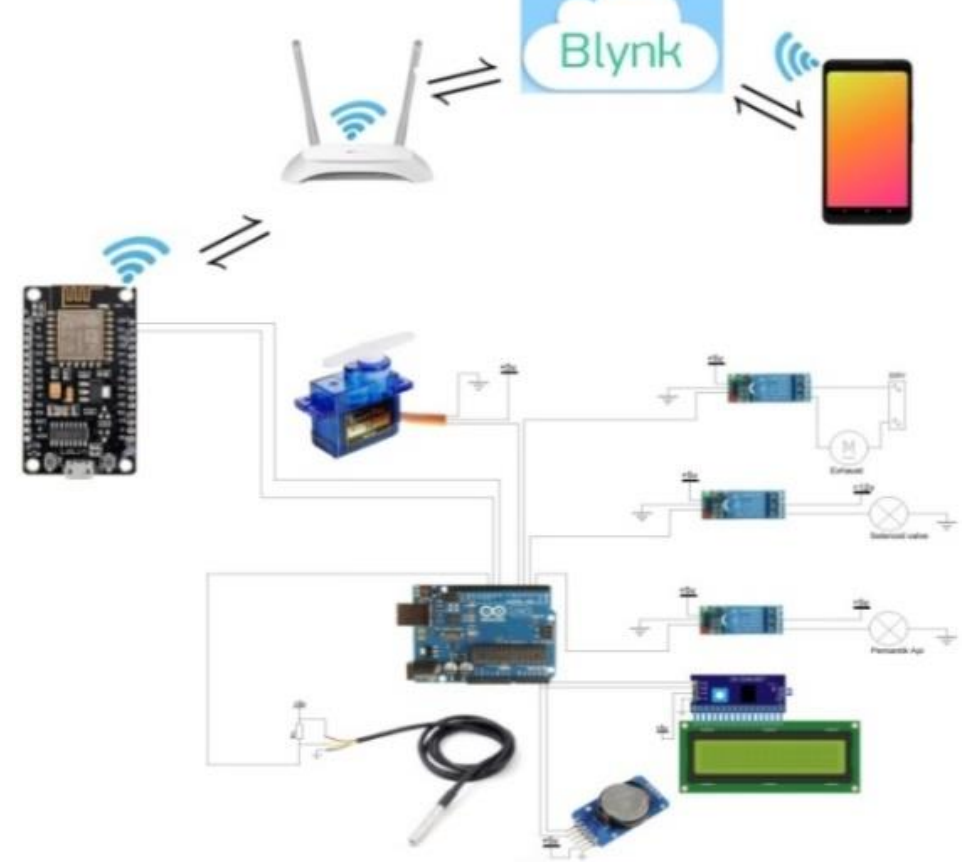

Figure 10. Skema Rangkaian Elektrik Burner Control Mesin Oven.

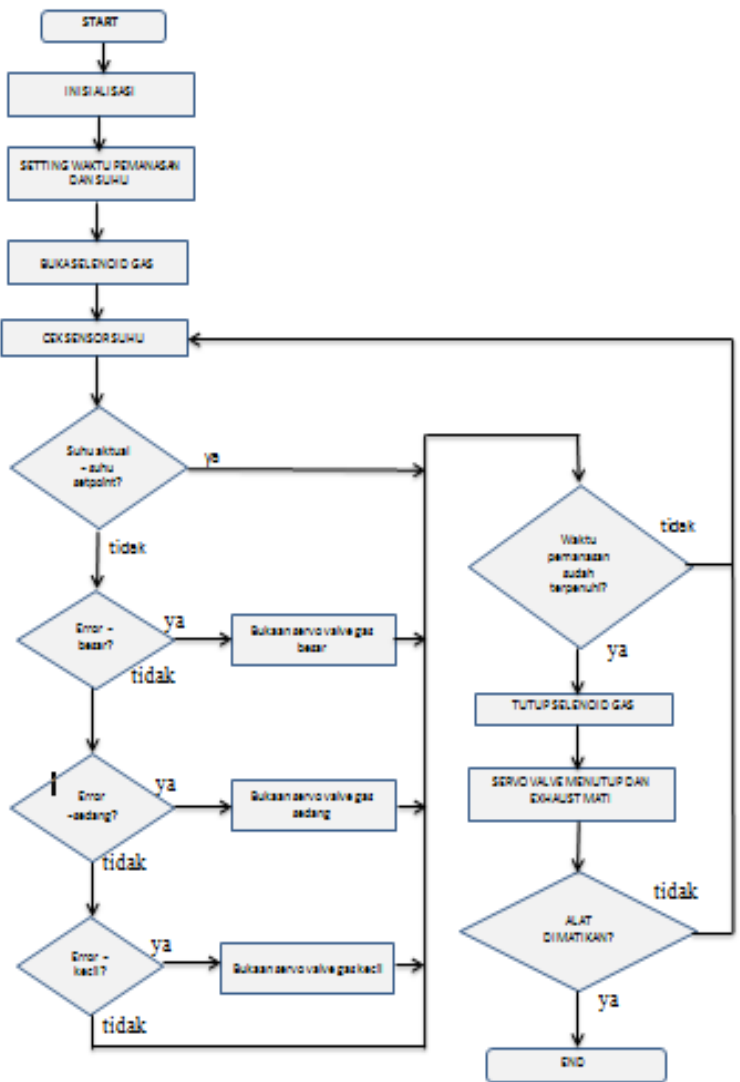

Figure 11. Flow Chart Pada Arduino 


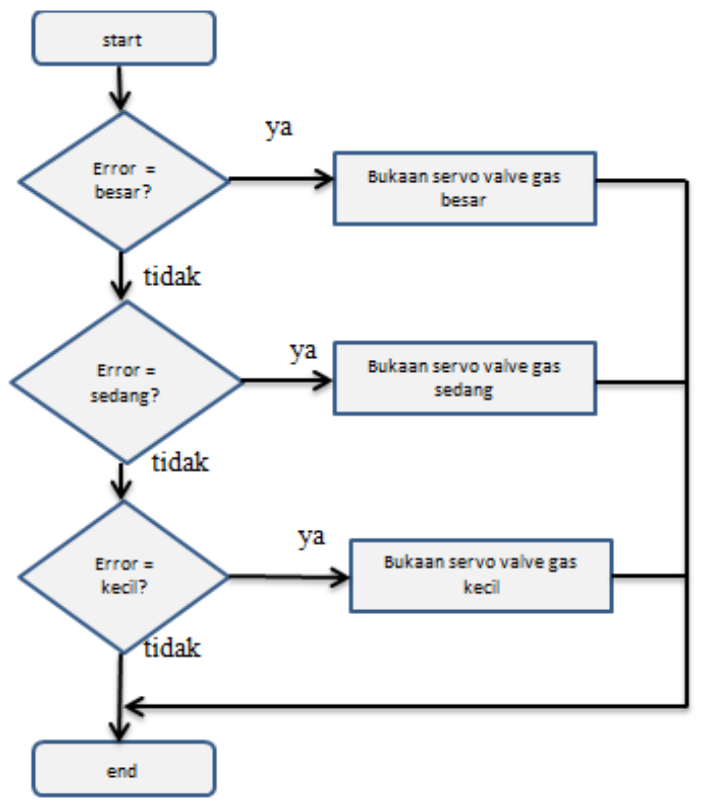

Figure 12. Flowchart Logika Fuzzy

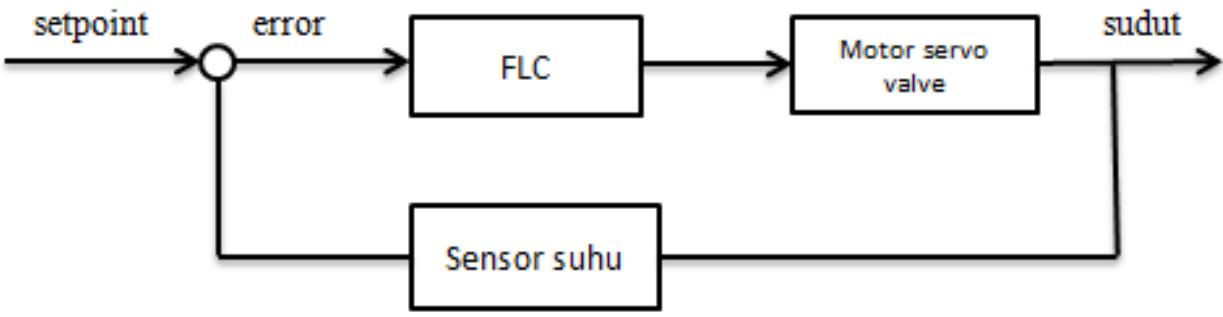

Figure 13. Flowchart Sistem Kendali Fuzzy

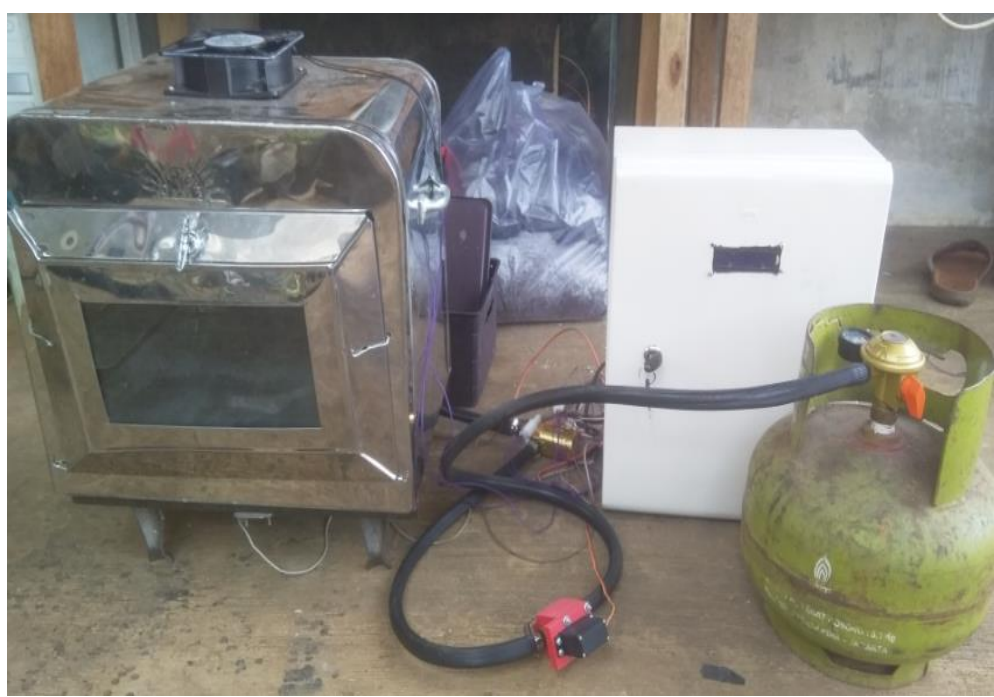

Figure 14. Perancangan Sistem Secara Keseluruhan 
F.

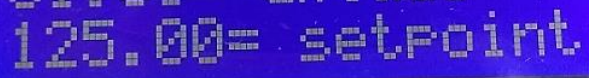

95. $1^{\prime}=$ errar

$18: 27=$ 연.t.

$5=t i n$

Big=

Figure 15. Tampilan Pada LCD

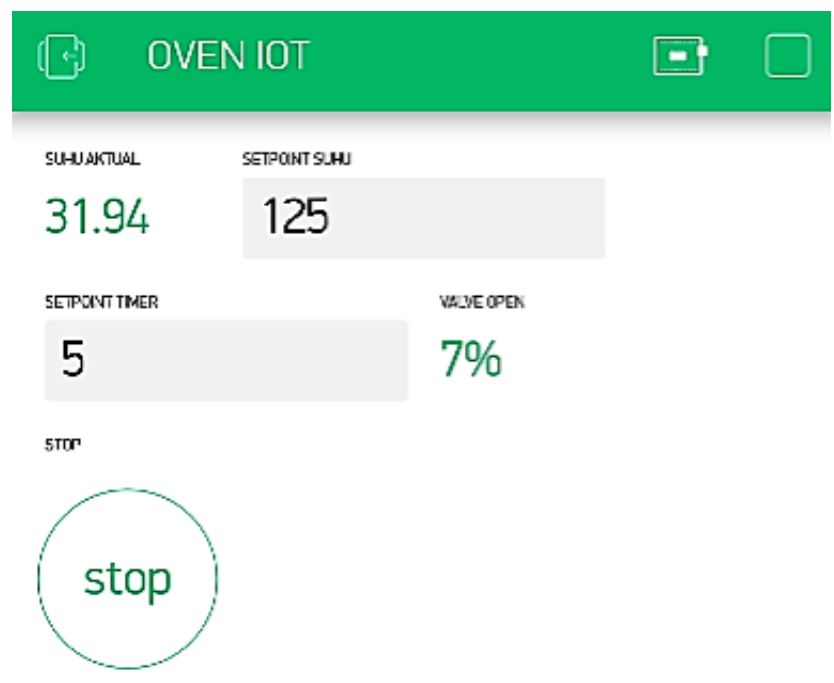

Figure 16. Tampilan Pada Aplikasi Blynk

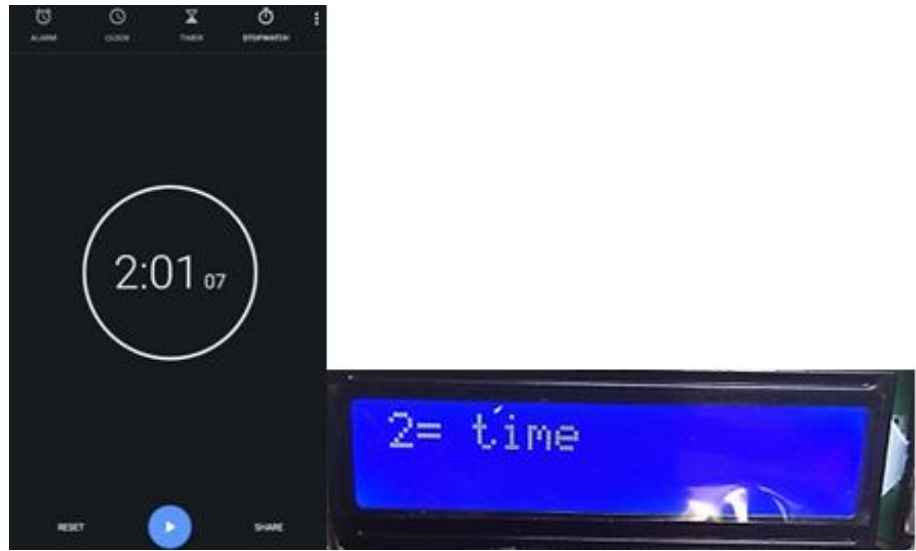

Figure 17. Pengujian Timer 


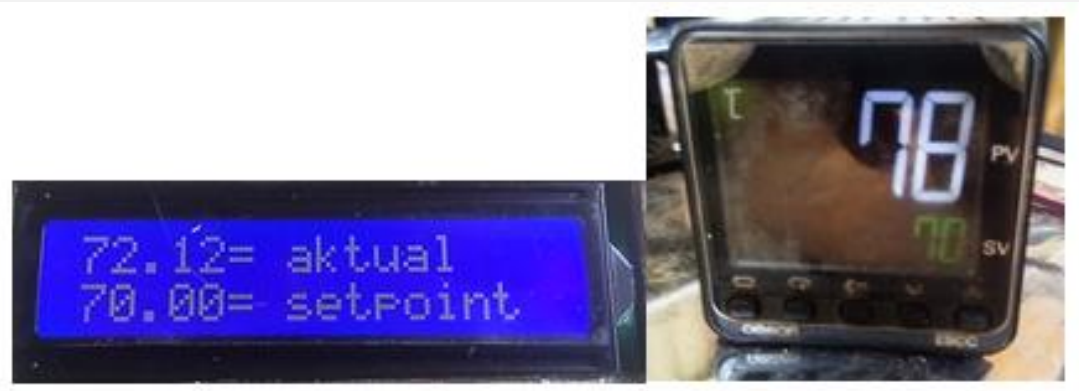

Figure 18. Pengujian Suhu Mesin Oven

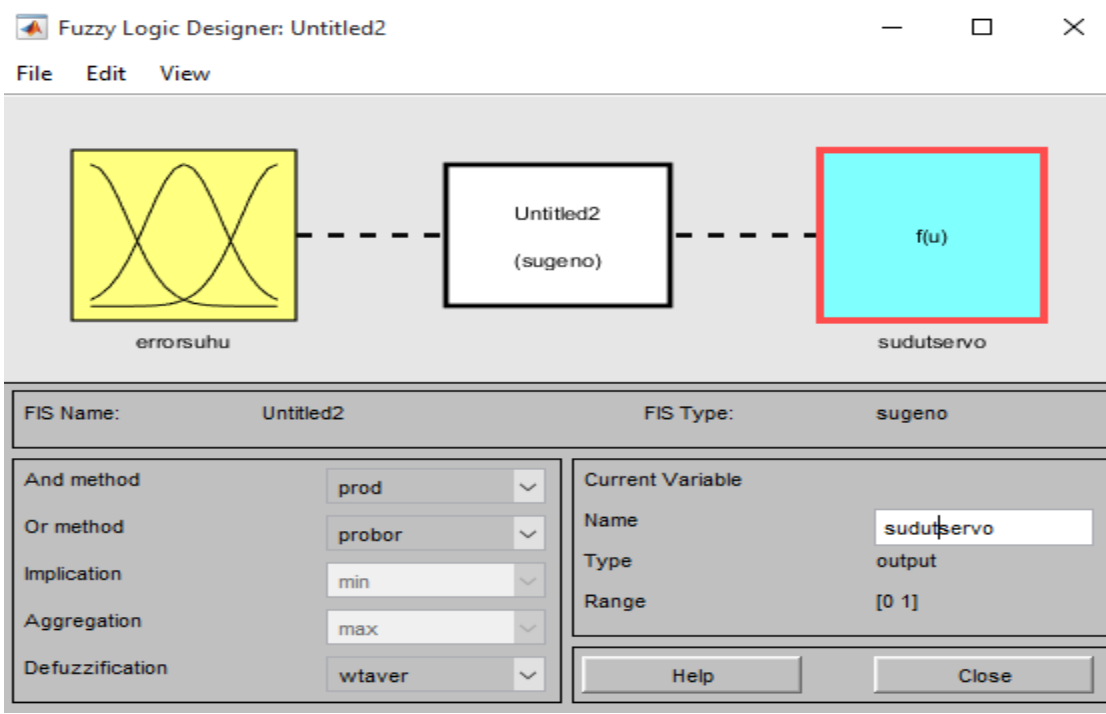

Figure 19. Rancangan Sistem Fuzzy

A Membership Function Editor: Untitled?

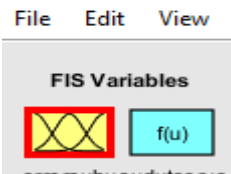

errorsuhusudutseno

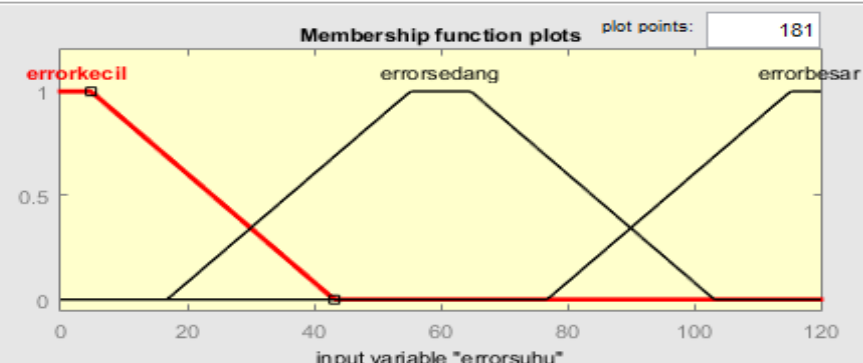

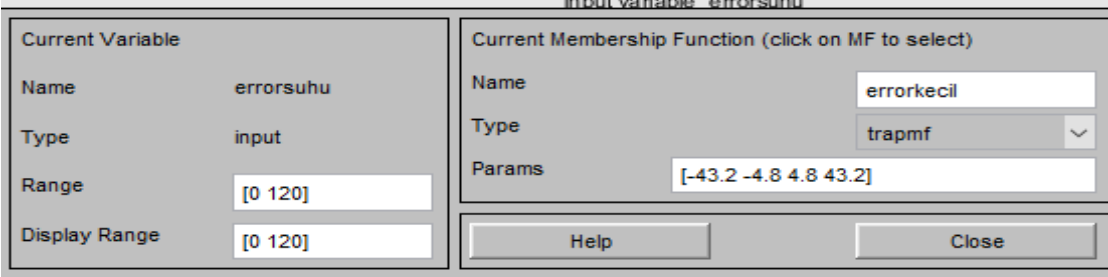

Selected variable "errorsuhu"

Figure 20. Fungsi Keanggotaan Error Suhu 
$\pi \sqrt{7} \mathbb{7}$ Journal of Electrical and Electronic Engineering-UMSIDA

ISSN 2460-9250 (print), ISSN 2540-8658 (online)

Vol. 5, No. 1, April 2021

Aembership Function Editor: Untitled2

File Edit View

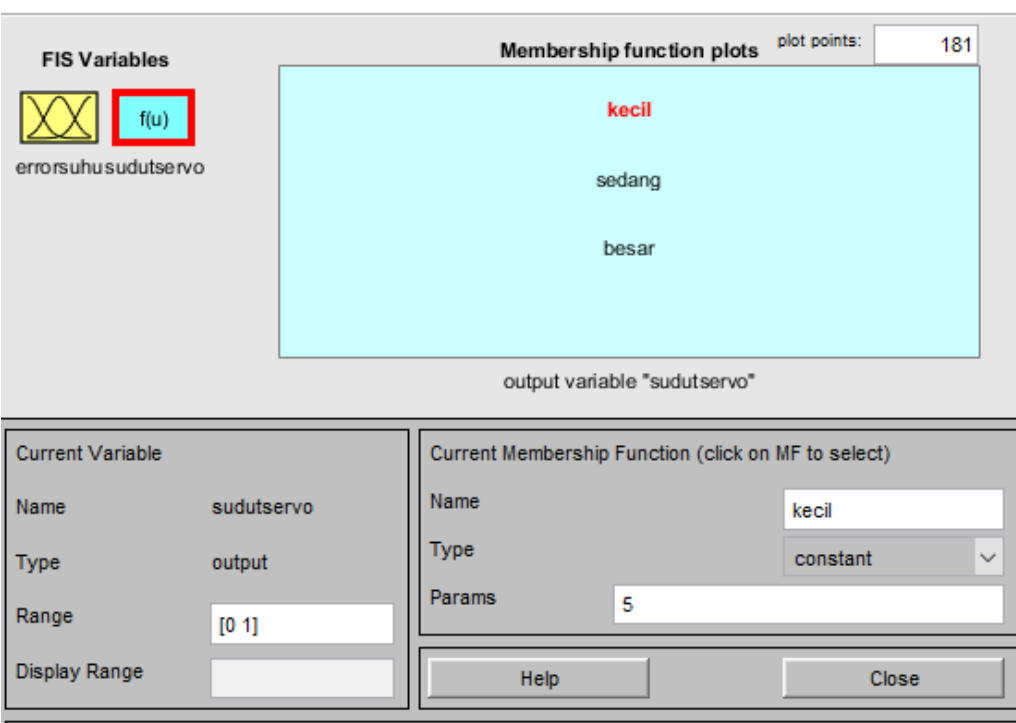

Changing parameter for MF 1 to 70

Figure 21. Fungsi Keanggotaan Output Servo

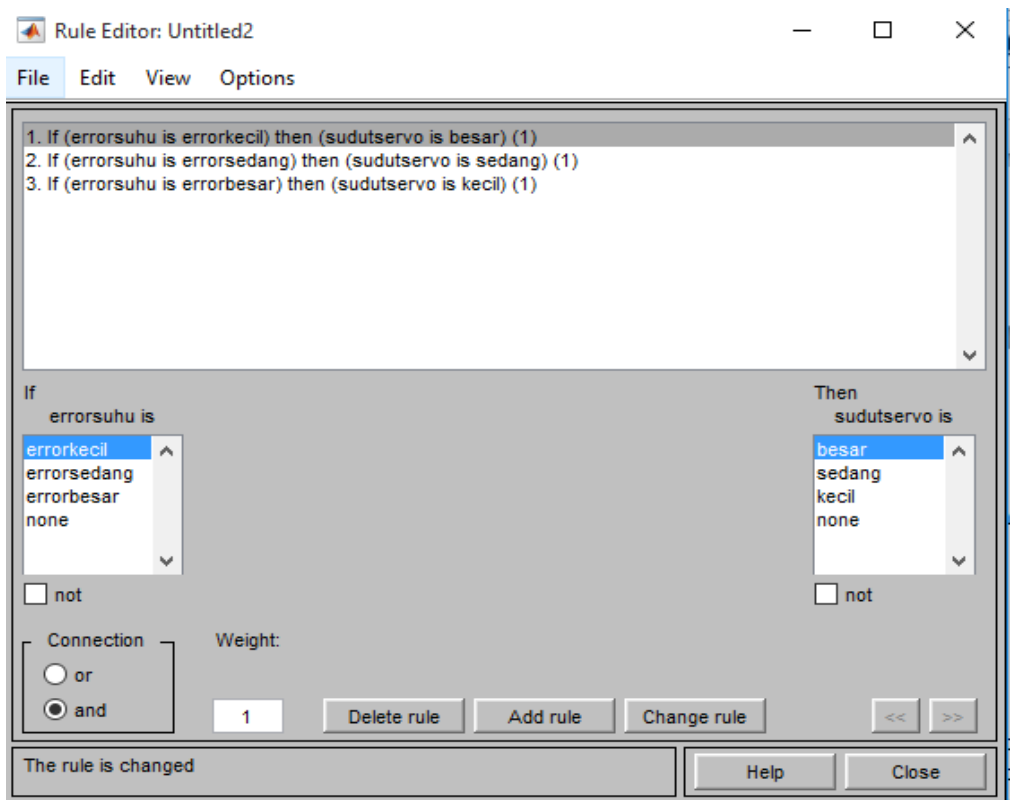

Figure 22. Fuzzy Rule

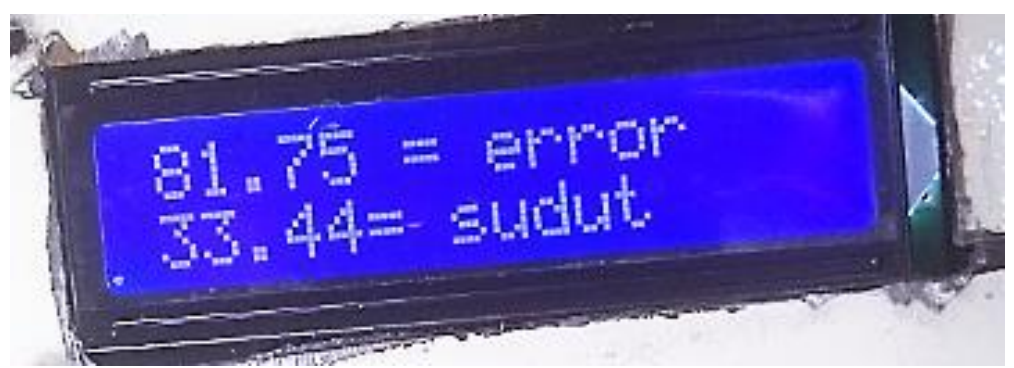

Figure 23. Tampilan LCD 
$\sqrt{4} \vec{G}] 7$ Journal of Electrical and Electronic Engineering-UMSIDA

ISSN 2460-9250 (print), ISSN 2540-8658 (online)

Vol. 5, No. 1, April 2021

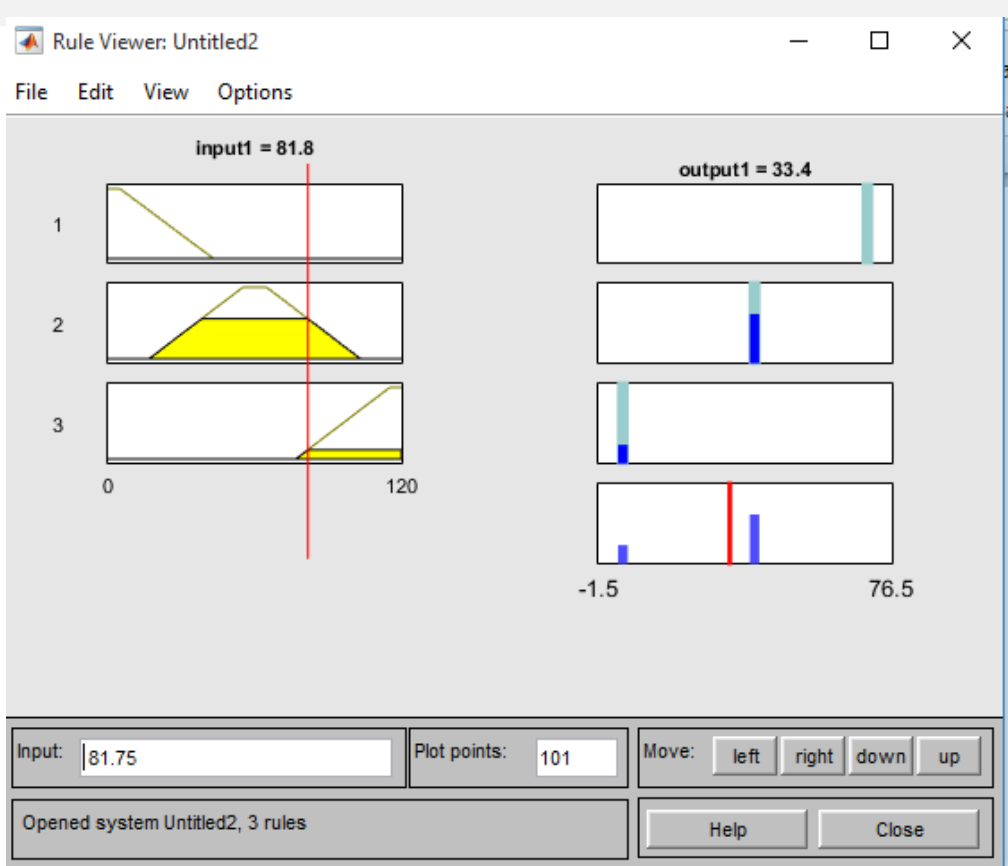

10.21070/jeeeu.v5i1.1005

Figure 24. Tampilan Rule Viewer Matlab 